\title{
EFEKTIVITAS BERKUMUR DENGAN AIR REBUSAN GAMBIR TERHADAP PERUBAHAN INDEKS PLAK PADA MAHASISWA KEPERAWATAN GIGI POLITEKNIK KESEHATAN KEMENKES MAKASSAR
}

\author{
Lucia Yauri, Ellis Mirawati
}

\begin{abstract}
ABSTRAK
Studi ini meneliti tentang efektivitas berkumur dengan air rebusan gambir terhadap perubahan indeks plak pada mahasiswa Keperawatan Gigi Poltekkes Kemenkes Makassar. Sejak lama masyarakat telah mengenal dan memanfaatkan tanaman obat-obatan alamiah yang berasal dari tumbuhtumbuhan.Obat-obat alamiah disamping harganya lebih murah juga lebih mudah diperoleh disekitar kita dan efek samping yang diakibatkan oleh penggunaan bahan alami lebih ringan dari bahan-bahan obat yang dibuat secara sintesis. Gambir adalah sari getah yang diekstraksi dari daun dan ranting tanaman gambir yang mengandung katekin sehingga dapat dijadikan obat kumur untuk menghilangkan plak. Sampel yang digunakan pada penelitian ini sebanyak 60 orang. Penelitian ini dilakukan di Kampus Poltekkes Kemenkes Makassar.Metode Penelitian ini adalah Quasi experimental secara cross-sectional dengan rancangan preposttest with control group design. Pelaksanaan dilakukan dengan pemeriksaan indeks plak awal dan Sampel yang terdiri dari 60 mahasiswa, dibagi menjadi 2 kelompok yaitu kelompok perlakuan dan kelompok kontrol. Pengolaan data pada penelitian ini menggunakan program komputer SPSS, dengan uji normalitas Shapiro-Wilk, paired T-test, independent T-test, dan disajikan dalam bentuk tabel distribusi. Hasil penelitian menunjukkan berkumur menggunakan air rebusan gambir efektif terhadap perubahan indeks plak.
\end{abstract}

Kata Kunci : Berkumur, Gambir, Plak

\section{PENDAHULUAN}

Kesehatan gigi dan mulut merupakan salah satu masalah dalam bidang kesehatan yang menjadi perhatian bagi tenaga kesahatan. Berdasarkan hasil Riset Kesehatan Dasar Nasional (Riskesdas) tahun 2018 menyebutkan bahwa $45,3 \%$ penduduk Indonesia mempunyai masalah kesehatan gigi dan mulut dan hanya $6,7 \%$ penduduk diantaranya yang menerima konseling perawatan kebersihan dan kesehatan gigi dan mulut dari tenaga kesehatan gigi. Hal ini mengidentifikasikan bahwa masih terdapat masyarakat yang belum menyadari pentingnya pemeliharaan kesehatan gigi dan mulut.(Riskesdas,2018)

Berdasarkan hasil riskesdas diatas menyatakan bahwa penduduk Indonesia mempunyai masalah kesehatan gigi dan mulut. Penyebab kesehatan gigi dan mulut adalah plak. Plak gigi adalah lapisan lunak dan lengket yang melekat pada gigi. Plak terdiri dari protein dan bakteri. $70 \%$ dari bakteri itu barasal dari air liur. Plak mulai mengeras oleh kalsium, fospor, dan mineral lainnya dan menjadi karang gigi hanya dalam waktu 48 jam setelah pembentukannya. (Mumpuni \& Pratiwi, 2013)

Sejak lama masyarakat telah mengenal dan memanfaatkan tanaman obat-obatan alamiah yang berasal dari tumbuh-tumbuhan. Obat-obat alamiah disamping harganya lebih murah juga lebih mudah diperoleh disekitar kita dan efek samping yang diakibatkan oleh penggunaan bahan alami lebih ringan dari bahan-bahan obat yang dibuat secara sintesis.

Gambir adalah sari getah yang diekstraksi dari daun dan ranting tanaman gambir. Bangsa Monggolia memanfaatkan getah gambir sebagai bahan pencampur sirih, sehingga pembudidayaan tanaman ini menjadi berkembang pesat. (Amos, 2009)

Di Sumatera gambir dikenal dengan nama yaitu, gambe (Aceh), sontang (Batak), gambie (Minangkabau), kacu (Gayu), pangilom dan sepelet (Lampung), di Jawa yaitu, gambir (Jawi), ghambir (Madura), di Kalimantan yaitu, kalare (Dayak), abi (Kayan), di Sulawesi yaitu, gambere (Sangir), gambele (Majene), di Nusatenggara yaitu, tagambe (Bima), gamur (Sumba), gati (Sawu), gambe (Flores), di Maluku 
yaitu, gabi (Halmahera), gambe (Ternate). (fzn, 1986)

Gambir dengan kandungan dua komponen utama yaitu katekin dan asam katekutannat mempunyai banyak manfaat. Gambir memiliki daya astringensi ,antibakteri, dan sifat-sifat farmakologis. Sifat-sifat ini menyebabkan gambir banyak digunakan dalam berbagai bidang industri, seperti industri obatobat dan farmasi, industri penyamakan kulit,dan lain-lain. (Amos, 2009)

Sebagai antibakteri, gambir dalam obat kumur diharapkan mampu membunuh ataupun menghambat pertumbuhan bakteri penyebab plak gigi. Bakteri yang berperan penting dalam pembentukan plak gigi adalah bakteri streptococcus mutans. (Amos, 2009)

\section{METODE PENELITIAN}

Metode yang digunakan pada Penelitian ini adalah quasi experimental dengan rancangan pretest-posttest with control group design. Penelitian dilakukan di Kampus Polteknik Kesehatan (Poltekkes) Kemenkes Makassar. Populasi dalam penelitian ini adalah mahasiswa D3 Kesehatan Gigi Poltekkes Kemenkes Makassar. Metode pengambilan sampel yang digunakan adalah Random sampling. Sampel dalam penelitian ini berjumlah 60 . Dalam hal ini terdiri atas 30 Sampel kelompok perlakuan yang berkumur dengan air rebusan gambir, dan 30 sampel kelompok kontrol yang berkumur dengan air mineral. Pengolaan data pada penelitian ini menggunakan program komputer SPSS, dengan uji normalitas Shapiro-Wilk, paired T-test, dan independent T-test.

\section{HASIL DAN PEMBAHASAN}

Dari penelitian yang dilakukan, didapatkan hasil sebagai berikut:

Tabel 1. Distribusi Subjek Berdasarkan Jenis Kelamin

\begin{tabular}{|c|c|c|c|c|c|c|}
\hline \multirow{2}{*}{$\begin{array}{c}\text { Jenis } \\
\text { kelamin }\end{array}$} & \multicolumn{2}{|c|}{ Perlakuan } & \multicolumn{2}{c|}{ Kontrol } & \multicolumn{2}{|c|}{ Total } \\
\cline { 2 - 7 } & $\mathrm{N}$ & $\%$ & $\mathrm{n}$ & $\%$ & $\mathrm{n}$ & $\%$ \\
\hline Laki-laki & 11 & 52 & 10 & 48 & 21 & 35 \\
\hline Perempuan & 19 & 49 & 20 & 51 & 39 & 65 \\
\hline Total & 30 & & 30 & & 60 & 100 \\
\hline
\end{tabular}

Tabel 1 menunjukkan subjek penelitian pada kelompok perlakuan air rebusan gambir dan kelompok kontrol air mineral berdasarkan jenis kelamin didapatkan jumlah sampel terbanyak perempuan .Berdasarkan kategori indeks plak sebelum berkumur air rebusan gambir didapatkan siswa memiliki indeks plak pada kategori sedang dan buruk. Berdasarkan kategori indeks plak sesudah berkumur air rebusan gambir didapatkan siswa memiliki indeks plak dengan kategori baik dan sedang (Tabel 2)

Berdasarkan kategori indeks plak sebelum berkumur air mineral didapatkan mahasiswa memiliki indeks plak pada kategori sedang dan buruk. Berdasarkan kategori indeks plak sesudah berkumur air mineral didapatkan mahasiswa memiliki indeks plak dengan kategori baik dan sedang (Tabel 3) 
Tabel 2. Hasil Kategori Indeks Plak Gigi Sebelum dan Sesudah Berkumur Air Rebusan Gambir

\begin{tabular}{|c|c|c|r|c|}
\hline & Indeks plak & Kategori & $\mathbf{n}$ & $\%$ \\
\hline \multirow{4}{*}{ Sebelum } & 0 & Sangat Baik & 0 & 0 \\
\cline { 2 - 5 } & $0,1-0,9$ & Baik & 0 & 0 \\
\cline { 2 - 5 } & $1,0-1,9$ & Sedang & 16 & 53,3 \\
\cline { 2 - 5 } & $2,0-3,0$ & Buruk & 14 & 46,7 \\
\cline { 2 - 5 } & Total & & 30 & 100 \\
\hline \multirow{5}{*}{ Sesudah } & 0 & Sangat Baik & 0 & 0 \\
\cline { 2 - 5 } & $0,1-0,9$ & Baik & 16 & 53,3 \\
\cline { 2 - 5 } & $1,0-1,9$ & Sedang & 14 & 46,7 \\
\cline { 2 - 5 } & $2,0-3,0$ & Buruk & 0 & 0 \\
\cline { 2 - 5 } & Total & & 30 & 100 \\
\hline
\end{tabular}

Tabel 3. Hasil Kategori Indeks Plak Gigi Sebelum dan Sesudah Berkumur Dengan Air Mineral

\begin{tabular}{|c|c|c|c|c|}
\hline & Indeks plak & Kategori & $\mathbf{n}$ & $\%$ \\
\hline \multirow{4}{*}{ Sebelum } & 0 & Sangat Baik & 0 & 0 \\
\cline { 2 - 5 } & $0,1-0,9$ & Baik & 0 & 0 \\
\cline { 2 - 5 } & $1,0-1,9$ & Sedang & 18 & 60,0 \\
\cline { 2 - 5 } & $2,0-3,0$ & Buruk & 12 & 40,0 \\
\cline { 2 - 5 } & Total & & 30 & 100 \\
\hline \multirow{4}{*}{ Sesudah } & 0 & Sangat Baik & 0 & 0 \\
\cline { 2 - 5 } & $0,1-0,9$ & Baik & 4 & 13,3 \\
\cline { 2 - 5 } & $1,0-1,9$ & Sedang & 26 & 86,7 \\
\cline { 2 - 5 } & $2,0-3,0$ & Buruk & 0 & 0 \\
\cline { 2 - 5 } & Total & & 30 & 100 \\
\hline
\end{tabular}

Hasil uji normalitas menggunakan

Shapiro-Wilk pada nilai indeks plak sebelum dan sesudah berkumur air rebusan gambir dan air mineral menunjukkan nilai signifikan lebih dari $0,05$ ( $p>0,05)$, sehingga dapat dikatakan bahwa data terdistribusi secara normal. Hasil uji statistik menggunakan paired $T$-test terdapat perbedaan signifikan nilai rerata indeks sebelum dan sesudah berkumur menggunakan air rebusan gambir dan sebelum dan sesudah berkumur menggunakan air mineral. Selisih rerata penurunan indeks plak setelah berkumur dengan air rebusan gambir adalah 0,84 , sedangkan air mineral 0,61. Hasil uji statistik menggunakan independent T-test didapat $\mathrm{p}=0,0$, hal ini menunjukkan berkumur air rebusan gambir lebih efektif dalam penurunan plak daripada berkumur air mineral.

\section{PEMBAHASAN}

Berdasarkan hasil analisis data menggunakan paired T-test pada kelompok perlakuan air rebusan gambir dan kelompok kontrol air mineral sebelum dan sesudah berkumur diperoleh hasil bahwa terdapat perbedaan yang signifikan antara sebelum dan 
sesudah berkumur air rebusan gambir dan berkumur air mineral. Berdasarkan hasil analisis berkumur menggunakan air rebusan gambir dan berkumur menggunakan air mineral memiliki efektifitas yang sama dapat menurunkan indeks plak. Dari hasil tersebut maka dilakukan uji perbandingan menggunakan uji independent T-test untuk melihat manakah yang lebih efektif dari kelompok berkumur menggunakan air rebusan gambir dan berkumur menggunakan air mineral dalam menurunkan indeks plak. Setelah dilakukan uji independent T-test didapatkan penurunan indeks plak berkumur menggunakan air rebusan gambir lebih efektif dibandingkan berkumur air mineral. Dalam hal ini peneliti berpendapat bahwa berkumur air rebusan gambir lebih efektif dalam menurunkan indeks plak dari pada berkumur menggunakan air mineral.

Penurunan indeks plak yang terjadi setelah berkumur air rebusan gambir disebabkan katekin yang terkandung pada gambir dapat menghambat pembentukan insoluble glukan dari sukrosa oleh glukosiltransferase (enzim yang diproduksi oleh bakteri Streptococcus) yang berperan penting dalam pembentukan plak.(Susilowati \& Sumarwati, 2012)

\section{KESIMPULAN}

Dari penelitian yang dilkakukan mengenai Efektivitas Berkumur dengan Air Rebusan Gambir Terhadap Perubahan Indeks Plak Pada Mahasiswa Keperawatan Gigi Poltekkes Kemenkes Makassar dapat disimpulkan sebagai berikut :

1. Sebelum berkumur air rebusan gambir tidak terdapat responden yang memiliki kriteria plak yang baik, 16 responden yang memiliki kriteria plak sedang $(53,3 \%)$, lalu 14 responden yang memiliki kriteria plak yang buruk $(46,7 \%)$.
2. Sesudah berkumur air rebusan gambir tidak terdapat responden yang memiliki kriteria plak sangat baik, 16 responden memiliki kriteria plak yang baik (53,3\%), Lalu 14 responden memiliki kriteria plak sedang $(46,7 \%)$, Kemudian tidak terdapat responden yang memiliki kriteria plak buruk.

3. Berkumur air rebusan gambir lebih efektif dalam perubahan indeks plak.

\section{SARAN}

Perlu penelitian lebih lanjut untuk mendapatkan hasil yang lebih akurat dan spesifik terhadap penentuan golongan bakteri yang mana yang paling bisa dihambat pertumbuhannya oleh air rebusan gambir sehingga dapat menambah pengetahuan lebih.

\section{DAFTAR PUSTAKA}

Amos. (2009). Gambir Sebagai Antibakteri Dalam Formulasi Obat Kumur. Jurnal Sains dan Teknologi Indonesia Vol.11 No.3, hal.188-192.

Fzn, H. Z. (1986). Tanaman Pinang dan Gambir. Bandung.

Kementrian Kesehatan RI. Hasil Utama RISKESDAS 2018. Avaible from: www.depkes.go.id/article/view/1811020 0003/potret;sehat;indonesia;dari;riskes das;2018.htm/

Mumpuni, Y., \& Pratiwi, E. (2013). 45 Masalah dan Solusi Penyakit Gigi dan Mulut. Yogyakarta: Rapha Publishing.

Susilowati, A., \& Sumarawati, T. (2012). Kajian Lama Kumur Air Rebusan Gambir (Uncaria gambir) terhadap Pembentukan Plak Gigi. Vol.4,No.1, 58. 